ORIGINAL RESEARCH PAPER

\title{
EFFECT OF GAMMA IRRADIATION AND STORAGE ON THE SYRIAN OLIVE CULTIVAR KAISSY (OLEA EUROPAEA) OIL PROPERTIES
}

\author{
MAHFOUZ AL-BACHIR ${ }^{1 *}$, YAHIA KOUDSI ${ }^{2}$ \\ ${ }^{1}$ Rad. Tech. Dept. , Atomic Energy Commission of Syria, Damascus, P.O. Box 6091, Syrian Arab \\ Republic. \\ ${ }^{2}$ Faculty of Science, Damascus University, Damascus, Syria. \\ *Corresponding author: ascientific@aec.org.sy \\ Received on 5 April 2018 \\ Revised on 10 April 2019
}

\begin{abstract}
The purpose of the current work was to evaluate the influence of gamma irradiation and storage period on the stability of physicochemical characteristics of olive oil. Olive (Olea Europaea) oil (OO) was extracted from fruits of Kaissy cultivar widely grown in Syria and treated with 1, 2 and $3 \mathrm{kGy}$ doses of gamma irradiation, and stored at room temperature up to 36 months. Results indicated that gamma irradiation significantly $(\mathrm{p}<0.01)$ increased the oil acidity (acid value) (AV) (Oleic acid \%), iodine value (IV), specification value (SV), and viscosity, and significantly decrease $(p<0.05)$ the refractive index $(\mathrm{RI})$, while no significant effect of irradiation was detected on peroxide value (PV). Lower doses of gamma irradiation (1 and $2 \mathrm{kGy}$ ) significantly decreased the TBA number (Thiobarbituric acid), whereas, the $3 \mathrm{kGy}$ dose significantly increased the TBA number. During storage, there was a significant increase $(\mathrm{p}<0.01)$ in AV, PV, RI, TBA and viscosity of Kaissy Olive Oil (KOO) samples. However, during storage, a significant decrease $(\mathrm{p}<0.01)$ in SV of irradiated KOO samples was detected. The studied qualitative characteristics including AV, PV, IV, SV, RI, TBI and viscosity of olive oil were significantly influenced by gamma irradiation used doses and storage time.
\end{abstract}

Keywords: virgin olive oil, hydrolytic rancidity, oxidative rancidity, Kaissy cultivar, olive oil quality

\section{Introduction}

Olive oil is very popular for its nutritive and health-promoting potential, which are due to the presence of high levels of monounsaturated fatty acids mainly oleic acids (68.15-70.80\%) and other valuable minor components with multiple biological activities such as hydrocarbons, sterols, aliphatic, alcohols, tocopherols, and pigments (Barbaro et al., 2014; Al-Bachir, 2017). The International Olive Council (IOC) defined the quality of olive oil, that depend mainly on several parameters including free fatty acid (FFA) content, peroxide value (PV) and

https//doi.org/10.35219/foodtechnology.2019.1.09 
sensory score (IOC, 2001). The major grades of edible olive oil are extra virgin, virgin, olive- pomace, and refined olive oils. The difference between extra virgin and virgin oils is the level of allowed free fatty acids (less than $0.8 \%$ for extra virgin versus $2.0 \%$ for virgin) and the absence of "sensory defects" in extra virgin olive oil (EVOO) (Baiano et al., 2014; Blatchly et al., 2014). Olive oil resistance against the oxidation process is an important indicator of performance and shelf life. High oxidative resistance is attributed to both triacylglycerol composition low in polyunsaturated fatty acids (PUSFA) and a group of phenolic antioxidants composed mainly of polyphenols and tocopherols (Velasco and Dobarganes, 2002; Jenisova et al., 2014). One of the most sever quality problems of virgin olive oil is its oxidative rancidity due to oxidation of unsaturated fatty acids and a subsequent formation of compounds that possess unpleasant taste and odor (Papadimitriou et al., 2006). In general, oil is oxidized when exposed to oxygen, heating, and light (Jenisova et al., 2014).

Food irradiation technology is an established method employed by several countries to prevent microorganisms division, thereby preventing food spoilage (Al-Bachir, 2013). Irradiation effects on food depends on the radiation application dose and dosage which are categorized into low ( $\leq 1 \mathrm{kGy})$, medium $(1-10 \mathrm{kGy})$, and high doses ( $\geq 10 \mathrm{kGy}$ ) (Olotu et al., 2014). Food irradiation was used for many purposes including the inhibition of sprouting, destruction of food borne insect's band parasites, delay of physiological ripening, and extension of shelf life or improvement of food qualities (Al-Bachir, 2004; Al-Bachir and Zeino, 2006). Several studies have found that irradiation induces changes in the oil composition (Al-Bachir, 2004; 2014; 2015a. 2015b). Food compounds stability needs also to be evaluated for normalization of the irradiation process (Erkan and Ozden, 2007). Therefore, these results indicate that further investigation is necessary to elucidate changes in oils induced by gamma irradiation. This work aimed to evaluate the influence of gamma irradiation (1, 2 and $3 \mathrm{kGy})$ and storage time $(6,12,24$ and 36 months) on the stability of physicochemical characteristics of Syrian Kaissy Olive Oil (SKOO).

\section{Materials and methods}

\section{Materials}

The study was carried out on Kaissy, the most widespread olive cultivar in Syria. Olive fruits were harvested during 2009/2010 production season, from trees grown in grove located at Deer Al Hajar research station, south Syrian region near Damascus $\left(33^{\circ} 21^{\prime} \mathrm{N}, 36^{\circ} 28^{\prime} \mathrm{E}\right)$ at $617 \mathrm{~m}$ above sea level. Olive fruits were weighed as in the sampling plan and transferred into polyethylene bags for irradiation. Each bag consisting of $1 \mathrm{~kg}$ olive fruits was considered as a replicate.

\section{Oil extraction}

The oils from olive fruits were extracted using mechanical and physical processes (Blatchly et al., 2014). Olive processing consisted of the following stages: milling and slowly mixed for about $30 \mathrm{~min}$ at $27^{\circ} \mathrm{C}$. Then, the paste mix was centrifuged at 
$3000 \mathrm{rpm}$ for $3 \mathrm{~min}$ to extract the oil. Finally, the oils were decanted, then immediately transferred into dark glass bottles and stored at room temperature (20 $-25{ }^{\circ} \mathrm{C}$ ) for further irradiation treatment and analyses. Physical and chemical analyses of irradiated and non-irradiated Syrian Kaissy Olive Oil (SKOO) samples were carried out immediately after irradiation, and after 6, 12, 24 and 36 months of storage.

\section{Treatment and analysis performed}

Irradiation was conducted using a ${ }^{60} \mathrm{CO}$ irradiator (ROBO, Techsnabexport, Moscow, Russia). Irradiation was carried out in the stationary mode of operation with a dose rate of $9.571 \mathrm{kGy} / \mathrm{h}$. The irradiations were performed at room temperature $\left(20-25{ }^{\circ} \mathrm{C}\right)$ and under normal atmospheric pressure. The absorbed dose was monitored using alcoholic chlorobenzene dosimeters (Al-Bachir, 2004).

\section{Chemical and physical analysis of oils}

Acidity value (AV) as (Oleic acid \%), peroxide value (PV) as meq $\mathrm{O}_{2} / \mathrm{kg}$ oil, iodine value (IV) in term of $\mathrm{g} \mathrm{I}_{2} / 100 \mathrm{~g}$, saponification (specification) value (SV) as $\mathrm{mg}$ $\mathrm{KOH} / \mathrm{g}$ oil sample and the refractive index (RI) at $25^{\circ} \mathrm{C}$ were evaluated according to standard methods (AOAC, 2010). TBA number (Thiobarbituric acid) in term of mg MDA kg ${ }^{-1}$ sample was determined according to IUPAC direct method (IUPAC, 1992). The viscosity values of the oils were determined with HAAKE viscometer 6R plus Model (RTM) using a R2 column at $200 \mathrm{rpm}$. Viscosity values were determined and expressed as $\mathrm{mPa} \times \mathrm{s}^{-1}$. The refractive index of olive oil samples was determined in daylight with an Abbe refractometer (VED Carl Zeiss JENA, German) calibrated against pure water at $25^{\circ} \mathrm{C}$.

\section{Statistical analysis}

Three replicates of each treatment were used and the entire assay was carried out in triplicate. The results were expressed as mean value and standard division (SD). Data regarding each parameter were analyzed using the SUPERANOVA computer package (Abacus Concepts Inc, Berkeley, CA, USA; 1998). The differences among means (at $\mathrm{p}<0.05$ were compared by using Duncan`s multiple rang test. The degree of significance was denoted as $\mathrm{p}<0.05^{*}, \mathrm{p}<0.01^{* *}$ (Snedecor and Cochran, 1988).

\section{Results and discussion}

\section{Physicochemical properties of Syrian Kaissy Olive Oil (SKOO)}

Average values of free fatty acids components of olive oil (non irradiated control sample) for the Syrian Kaissy cultivar olive fruits (SKOF), were expressed in percentages of oleic acid $(0.39 \%)$; the peroxide $\left(5.15 \mathrm{meq} \mathrm{O}_{2} / \mathrm{kg}\right.$ oil $)$; the TBA (0.0019 mg MDA $/ \mathrm{kg}$ oil); tiodine $\left(94.53 \mathrm{~g} \mathrm{I}_{2} / 100 \mathrm{~g}\right)$, saponification $(194.37 \mathrm{mg}$ $\mathrm{KOH} / \mathrm{g}$ oil), refractive index (1.4670), and viscosity $\left(137.67{\left.\mathrm{mPa} \times \mathrm{s}^{-1}\right)}^{-1}\right.$ (Table 1, 2 and 3$)$. As far as the physicochemical quality criteria are considered, keeping in mind the limits set by International Olive Council standard (IOC, 2015), the studied samples of olive oil fell into the 'Extra-virgin' olive oil category. These results were expected, since the raw materials was carefully selected, picked and processed. 
Table 1. Free fatty acid (\%), peroxide Value $\left(\mathrm{meqO}_{2} \mathrm{~kg}^{-1} \mathrm{Oil}\right)$, and TBA value (mg MDA $\mathrm{kg}^{-1}$ oil) of gamma irradiated Syrian Kaissy Olive Oil (SKOO) and stored for up to 36 months

\begin{tabular}{|c|c|c|c|c|c|}
\hline Treatment & Control & $1 \mathrm{KGY}$ & $2 \mathrm{KGY}$ & $3 \mathrm{KGY}$ & P-level \\
\hline \multicolumn{2}{|c|}{$\begin{array}{l}\text { Storage period } \\
\text { (Months) }\end{array}$} & \multicolumn{4}{|c|}{ Acid value (Free Fatty Acid \% } \\
\hline 0 & $0.39 \pm 0.05^{\mathrm{cE}}$ & $0.72 \pm 0.11^{\mathrm{bcD}}$ & $0.86 \pm 0.06^{\mathrm{abC}}$ & $1.28 \pm 0.49^{\mathrm{aB}}$ & ** \\
\hline 6 & $0.50 \pm 0.01^{\mathrm{cD}}$ & $1.00 \pm 0.08^{\mathrm{bB}}$ & $1.14 \pm 0.06^{\mathrm{aC}}$ & $1.03 \pm 0.08^{\mathrm{abC}}$ & $* *$ \\
\hline 12 & $0.62 \pm 0.03^{\mathrm{cC}}$ & $0.83 \pm 0.16^{\mathrm{cC}}$ & $0.87 \pm 0.06^{\mathrm{bC}}$ & $1.22 \pm 0.03^{\mathrm{aB}}$ & $* *$ \\
\hline 24 & $1.03 \pm 0.02^{\mathrm{aA}}$ & $1.83 \pm 0.05 \mathrm{bA}$ & $1.81 \pm 0.08^{\mathrm{bB}}$ & $2.39 \pm 0.03^{\mathrm{aA}}$ & $* *$ \\
\hline 36 & $0.72 \pm 0.03^{\mathrm{bB}}$ & $2.52 \pm 0.64^{\mathrm{aA}}$ & $2.11 \pm 0.32^{\mathrm{aA}}$ & $2.41 \pm 0.18^{\mathrm{aA}}$ & $* *$ \\
\hline P-level & $* *$ & $* *$ & $* *$ & $* *$ & \\
\hline \multicolumn{6}{|c|}{ Peroxide Value (meq $\mathrm{O}_{2} / \mathrm{kg}$ Oil) } \\
\hline 0 & $5.15 \pm 0.25^{\mathrm{aD}}$ & $4.03 \pm 0.96^{\mathrm{abD}}$ & $3.81 \pm 0.47^{\mathrm{bD}}$ & $4.69 \pm 0.78^{\mathrm{abD}}$ & NS \\
\hline 6 & $6.84 \pm 0.41^{\mathrm{aC}}$ & $7.31 \pm 0.23^{\mathrm{aC}}$ & $7.24 \pm 0.42^{\mathrm{aC}}$ & $6.98 \pm 0.41^{\mathrm{aC}}$ & NS \\
\hline 12 & $7.43 \pm 0.31^{\mathrm{aC}}$ & $7.18 \pm 0.81^{\mathrm{aC}}$ & $7.33 \pm 0.64^{\mathrm{aC}}$ & $7.10 \pm 0.88^{\mathrm{aC}}$ & NS \\
\hline 24 & $13.48 \pm 0.34^{\mathrm{aB}}$ & $11.15 \pm 1.16^{\mathrm{bB}}$ & $11.22 \pm 0.19^{\mathrm{bB}}$ & $13.05 \pm 0.59^{\mathrm{aB}}$ & $* *$ \\
\hline 36 & $14.28 \pm 0.63^{\mathrm{aA}}$ & $14.28 \pm 0.00^{\mathrm{aA}}$ & $14.40 \pm 0.12^{\mathrm{aA}}$ & $15.07 \pm 0.62^{\mathrm{aA}}$ & NS \\
\hline P-level & $* *$ & $* *$ & $* *$ & $* *$ & \\
\hline \multicolumn{6}{|c|}{ TBA value (mg MDA/kg oil) } \\
\hline 0 & $0.0019 \pm 0.00^{\mathrm{bD}}$ & $0.0016 \pm 0.00^{\mathrm{cD}}$ & $0.0013 \pm 0.00^{\mathrm{dD}}$ & $0.0028 \pm 0.00^{\mathrm{aB}}$ & $* *$ \\
\hline 6 & $0.0021 \pm 0.00^{\mathrm{aC}}$ & $0.0021 \pm 0.00^{\mathrm{aC}}$ & $0.0020 \pm 0.00^{\mathrm{abC}}$ & $0.0018 \pm 0.00^{\mathrm{bE}}$ & $*$ \\
\hline 12 & $0.0022 \pm 0.00^{\mathrm{aC}}$ & $0.0020 \pm 0.00^{\mathrm{aC}}$ & $0.0020 \pm 0.00^{\mathrm{aC}}$ & $0.0020 \pm 0.00^{\mathrm{aD}}$ & NS \\
\hline 24 & $0.0024 \pm 0.00^{\mathrm{aB}}$ & $0.0023 \pm 0.00^{\mathrm{aB}}$ & $0.0023 \pm 0.00^{\mathrm{aB}}$ & $0.0023 \pm 0.00^{\mathrm{aC}}$ & NS \\
\hline 36 & $0.0032 \pm 0.00^{\mathrm{bA}}$ & $0.0035 \pm 0.00^{\mathrm{aA}}$ & $0.0032 \pm 0.00^{\mathrm{bA}}$ & $0.0032 \pm 0.00^{\mathrm{bA}}$ & $* *$ \\
\hline P-level & $* *$ & $* *$ & $* *$ & $* *$ & \\
\hline
\end{tabular}

abc Significant difference between storage periods are presented with different superscript $\left({ }^{*} p<0.05\right.$, $* * \mathrm{p}<0.01)$.

${ }_{A B C}$ Significant difference between irradiation treatments are presented with different superscript $\left({ }^{*} \mathrm{p}<0.05, * * \mathrm{p}<0.01\right)$

NS: not significant.

\section{Effect of gamma irradiation and storage period on acidity value of SKOO}

Acid value (AV) is the measurement of free fatty acids (FFA) in oils. The quantity of free fatty acids, measured as acidity (\% oleic acid) is a very important quality and classification index for olive oils (Enujiugha et al., 2012). Acid value gives an indication of the suitability of oil for direct consumption and industrial use (AlBachir, 2015b). The measured AV indices of the irradiated and non-irradiated SKOO samples that were stored for $0,6,12,24$ and 36 months are shown in Table 1. The AV of $0.39 \%$ in the non-irradiated control samples of SKOO used in this study is under the IOC standard (IOC, 2015) of $0.8,2.0$ and $3.3 \mathrm{~g}$ FFA/100 g oil for extra virgin, virgin and ordinary virgin olive oils, respectively. Also, the free fatty acids content is an indicator of the level of hydrolytic rancidity of oil. It was found that the effect of irradiation treatment on AV of SKOO samples was statistically significant $(p<0.01)$. According to the research results, if the dose level of 
irradiation increases, acidity value increases proportionally. Irradiated SKOO with higher dose $(3 \mathrm{kGy})$ has significantly $(\mathrm{p}<0.01)$ highest acid value $(1.28 \%)$.

The acid value is an indication on the deterioration level of oil during storage. The acid value increased linearly during storage time studied (up to 36 months) (Table 1). A previous study showed that the activity of seed lipases could induce these oils to faster deterioration during storage (Enujiugha et al., 2004). Indeed, FFA were partly formed by hydrolysis of triacylglycerols, which was promoted by the presence of food moisture (Al-Harbi and Al-Kabtani, 1993). The studied samples of SKOO fell into the 'Extra-virgin' olive oil category, which has moisture of not more than $2 \mathrm{~g} / 100 \mathrm{~g}$ oil (IOC, 2015). It is known that the increase of free acidity is mainly due to enzyme activity caused by olive tissue damage (Zegane et al., 2015). The high degree of saturated fatty acids enables oil to be shelf life (Nwinuka and Barine, 2009). Fatty acids components are usually found in the form of triglycerides but they may decompose into free fatty acid components during storage or processing (Atinafu and Bedemo, 2011).

\section{Effect of gamma irradiation and storage period on peroxide value of SKOO}

Values of peroxide index of olive oil samples of the control and irradiated SKOO at different period of storage under study are given in Table 1. As can be seen, average value of peroxide index of non-irradiated control sample of SKOO was found to be $5.15 \mathrm{meq} \mathrm{O}_{2} / \mathrm{kg}$ oil. The peroxide value (PV) is an indicator of deterioration of fats. Peroxide formation is a major concern from the point of view of rancidity and toxicology. As oxidation takes place, the double bonds in the unsaturated fatty acids (USFA) attach forming peroxide. Fresh oils were shown to have peroxide values lower than 10 meq $\mathrm{O}_{2} / \mathrm{kg}$ oil and oil become rancid when PV ranges from 20 to $40 \mathrm{meq} \mathrm{O}_{2} / \mathrm{kg}$ oil (Enujiugha et al., 2012).

Results of the ANOVA test applied to PV data revealed that no statistically differences could be found among the studied gamma irradiation dosed considering this parameter $(\mathrm{p}>0.05)$. This did not conform to the findings of Enujiugha et al. (2012) who reported that irradiation at up to $10 \mathrm{kGy}$ significantly increased the peroxide value of oil extracted from African oil seed. During storage, there was a significant increase in the PV of control and irradiated samples of KSOO $(\mathrm{p}<0.01)$. After 36 months of storage, the PV of irradiated KSOO with $0,1,2$, and $3 \mathrm{kGy}$ were $14.28,14.28,14.40$, and 15.07 meq $\mathrm{O}_{2} / \mathrm{kg}$ oil respectively.

Most peroxide content in olive oil is organic hydroperoxides, which can originate due to mistreatment/spoilage of olives, during extraction or during storage if exposed to oxygen for long periods (Psomiadou and Tsimidou, 2002). Oxidation of the triglycerides and their derivates in virgin olive oil causes changes in the chemical, sensory and nutritional properties of oil that affect the quality of the oil (Velasco and Dobarganes, 2002). Therefore, high quality olive oils should have peroxide value of less than $20 \mathrm{meq} \mathrm{O}_{2} / \mathrm{kg}$ oil (Blatchly et al., 2014).

\section{Effect of gamma irradiation and storage period on TBA value of SKOO}

Thiobarbituric acid (TBA) values expressed as malondialdehyde (MDA) content of non irradiated SKOO was low (0.0019 mg MDA $/ \mathrm{kg}$ oil) (Table 1$)$. This may be 
due to the presence of antioxidant compounds such as tocopherols, which prevent lipid oxidation in food products (Al-Bachir and Zeino, 2006). TBA values of irradiated and non-irradiated SKOO samples were close to each other. Immediately after treatment, gamma irradiation doses of 1 and $2 \mathrm{kGy}$ significantly $(\mathrm{p}<0.01)$ decreased the TBA value of SKOO. While, $3 \mathrm{kGy}$ significantly $(\mathrm{p}<0.05)$ increased the TBA value of SKOO. These results are in agreement with those of Al-Bachir (2015b) who observed that lipid oxidation expressed as malondialdehyde (MDA) content of oil extracted from control samples of pistachio ( $0.023 \mathrm{mg} \mathrm{MDA} / \mathrm{kg}$ oil) was lower than those of oil extracted from samples treated with $3 \mathrm{kGy}(0.025 \mathrm{mg}$ MDA/kg oil). During storage period, the TBA values of both irradiated and non irradiated SKOO were constant until 24 moths of storage, Afterwards it increased significantly $(p<0.01)$ to be higher than 0.003 for non-irradiated and irradiated samples. This result may be attributed to higher amount of oleic and less amount of linoleic acid content of oils (Gamli and Hayoglu, 2007). Regarding the effect of storage time on the TBARS value, our results are in agreement with those of AlBachir (2015b) who observed that TBARS value, with respect to the oil extracted from irradiated and non-irradiated control samples of peanut seeds, increased with storage time.

\section{Effect of gamma irradiation and storage period on iodine value of SKOO}

Iodine value (IV) is the measure of the proportion of unsaturated acids present. The principle of IV is due to the reactivity of double bonds with halogens. The oil with high iodine value has high degree of un-saturation (Afify et al., 2013). The data presented in Table 2, illustrate that the IV of non-irradiated control sample of SKOO was $94.53 \mathrm{~g} \mathrm{I}_{2} / 100 \mathrm{~g}$ oil. The obtained results indicated that immediately after irradiation, 2 and $3 \mathrm{kGy}$ doses of gamma irradiation significantly $(\mathrm{p}<0.01)$ increased the IV of SKOO. The IV was 99.81 and $99.57 \mathrm{~g} \mathrm{I}_{2} / 100 \mathrm{~g}$ for SKOO treated with 2 and $3 \mathrm{kGy}$, respectively (Table 2). These results are in agreement with the results obtained by several investigators. Al-Bachir (2015a), who observed significant increase $(p<0.05)$ in IV for oil extracted from peanut seed treated with 3 kGy dose, IV increased $(\mathrm{p}<0.05)$ from an initial value of 107.24 to a value of $116.76 \mathrm{~g} \mathrm{I}_{2} / 100 \mathrm{~g}$ peanut oil after irradiation at dose of $3 \mathrm{kGy}$.

Other investigators found a decrease in iodine values of gamma irradiated oil seeds (Afify et al., 2013). During storage, there was a significant decrease $(p<0.01)$ in the IV of both control and irradiated SKOO samples. It was statistical different from the value of the irradiated and non-irradiated SKOO samples, when the analyses were performed after six and 12 months of storage, while it wasn 't statistical different $(\mathrm{p}>0.05)$ from the value of irradiated and non-irradiated samples, when the analyses were performing after 24 and 36 months of storage. After 36 months of storage, the IV of SKOO treated with $0,1,2$ and $3 \mathrm{kGy}$ were 87.57, 87.71, 84.85 and $86.05 \mathrm{~g} \mathrm{I}_{2} 100 / \mathrm{g}$ oil, respectively (Table 2). The decrease in iodine value may be attributed to the saturation of the double of un-saturated fatty acids bonds (AlBachir, 2004). 


\section{Effect of gamma irradiation and storage period on saponification value of SKOO}

The saponification value (SV) of the SKOO were determined in the present study. The SV of the un-irradiated control sample of SKOO was found as $194.37 \mathrm{mg} \mathrm{KOH} / \mathrm{g}$ oil (Table 2). The comparative SV indicates the presence of higher fatty acids in higher proportions. The high SV recorded for the SKOO suggest that the oils contained high molecular weight fatty acids and low level of impurities. This is evidence that the SKOO could be used in soap making industry (Al-Bachir, 2015a). The results presented in Table 2 indicate that, both storage time and irradiation doses showed significant effect on SV of SKOO $(p<0.05)$. SV in SKOO showed an increase for all irradiated SKOO samples $(p<0.01)$. Irradiated SKOO with $2 \mathrm{kGy}$ had greater SV $199.75 \mathrm{mg} \mathrm{KOH} / \mathrm{g}$ oil. Our results agree with Al-Bachir (2015a) who also observed an increase in SV in oil extracted from irradiated peanut seed with 1,2 and $3 \mathrm{kGy}$. The present findings were also in agreement with previous studies, where it were found that saponification values of oil extracted from irradiated almond was increased upon irradiation (an increase from 185-187 to 204$231 \mathrm{mg} \mathrm{KOH} / \mathrm{g}$ ) (Bhatti et al., 2013). Saponification values increased in oil samples irradiated with 1, 2 and $3 \mathrm{k}$ Gy, which indicated that large original molecules of oils containing long-chain fatty acids degraded/modified to smaller/bigger molecules as results of oxidation and cleavage of bonds (Agatemor, 2006). SV of non-irradiated (control) samples of olive oils, decreased during the first 12 months of storage, followed thereafter by a gradual increase until the 36 months. At the end of storage period (36 months), the SV of control samples of the SKOO were $194.75 \mathrm{mg} \mathrm{KOH} / \mathrm{g}$ oil (Table 2).

Table 2. Iodine number ( $\mathrm{g} \mathrm{I}_{2} / 100 \mathrm{~g}$ oil), and Saponification value ( $\mathrm{mg} \mathrm{KOH} / \mathrm{g}$ oil) of gamma irradiated Syrian Kaissy Olive Oil (SKOO) and stored for up to 36 months.

\begin{tabular}{|c|c|c|c|c|c|}
\hline Treatment & Control & $1 \mathrm{KGY}$ & 2 KGY & $3 \mathrm{KGY}$ & $\begin{array}{l}\text { P- } \\
\text { level }\end{array}$ \\
\hline \multicolumn{6}{|c|}{ Storage period/(Months) } \\
\hline \multicolumn{6}{|c|}{ Iodine number (g I/2/100gOil) } \\
\hline 0 & $94.53 \pm 0.57^{\mathrm{bA}}$ & $93.23 \pm 0.94^{\mathrm{cB}}$ & $99.81 \pm 0.21^{\mathrm{aA}}$ & $99.57 \pm 0.53^{\mathrm{aA}}$ & $* *$ \\
\hline 6 & $93.32 \pm 0.53^{\mathrm{bA}}$ & $96.22 \pm 0.41^{\mathrm{aA}}$ & $93.08 \pm 0.31^{\mathrm{bB}}$ & $93.91 \pm 0.76^{\mathrm{bB}}$ & $* *$ \\
\hline 12 & $88.52 \pm 0.04^{\mathrm{cB}}$ & $92.18 \pm 0.45^{\mathrm{aB}}$ & $89.55 \pm 0.14^{\mathrm{bC}}$ & $92.35 \pm 0.38^{\mathrm{aB}}$ & $* *$ \\
\hline 24 & $86.17 \pm 1.28^{\mathrm{aC}}$ & $86.05 \pm 2.58^{\mathrm{aC}}$ & $84.70 \pm 2.03^{\mathrm{aD}}$ & $86.72 \pm 1.22^{\mathrm{aC}}$ & NS \\
\hline 36 & $87.57 \pm 1.08^{\mathrm{abBC}}$ & $87.71 \pm 0.79^{\mathrm{aC}}$ & $84.58 \pm 1.69^{\mathrm{bD}}$ & $86.05 \pm 2.40^{\mathrm{abC}}$ & NS \\
\hline P-level & $* *$ & $* *$ & $* *$ & $* *$ & \\
\hline \multicolumn{6}{|c|}{$\begin{array}{l}\text { Saponification value (mg KOH/g oil) } \\
\end{array}$} \\
\hline 0 & $194.37 \pm 0.85^{\mathrm{cB}}$ & $197.06 \pm 0.83^{\mathrm{bB}}$ & $199.75 \pm 0.89^{\mathrm{aA}}$ & $196.68 \pm 0.97^{\mathrm{bC}}$ & $* *$ \\
\hline 6 & $199.25 \pm 0.79^{\mathrm{bAC}}$ & $199.01 \pm 0.84^{\mathrm{bA}}$ & $199.29 \pm 0.95^{\mathrm{bA}}$ & $201.97 \pm 0.93^{\mathrm{aA}}$ & $* *$ \\
\hline 12 & $198.94 \pm 0.14^{\mathrm{aC}}$ & $199.13 \pm 0.31^{\mathrm{aA}}$ & $198.12 \pm 0.33^{\mathrm{bB}}$ & $198.07 \pm 0.47^{\mathrm{bB}}$ & $*$ \\
\hline 24 & $194.65 \pm 0.89^{\mathrm{aB}}$ & $195.70 \pm 0.37^{\mathrm{aC}}$ & $195.12 \pm 0.30^{\mathrm{aC}}$ & $195.31 \pm 0.16^{\mathrm{aD}}$ & NS \\
\hline 36 & $194.75 \pm 3.20^{\mathrm{aB}}$ & $194.39 \pm 0.06^{\mathrm{aD}}$ & $194.45 \pm 0.12^{\mathrm{aC}}$ & $195.07 \pm 0.44^{\mathrm{aD}}$ & NS \\
\hline P-level & $* *$ & $* *$ & ** & $* *$ & \\
\hline
\end{tabular}




\section{Effect of gamma irradiation and storage period on refractive index of SKOO}

The refractive index (RI) of non irradiated SKOF at $25^{\circ} \mathrm{C}$ was 1.467 as can be seen from Table 3 . These results are very similar to those reported for sunflower oil (1.465), brassica oil (1.470), soybean oil (1.472), cottonseed oil (1.474), sesame oil (1.475) and linseed oil (1.478) (Biswas et al., 2001). These results indicate that all these varieties of oils contain fairly large amounts of unsaturated fatty acids, so cannot be stored for long, due to rancidity hazard. RI is the measure of thickness as well as purity or clarity of the oil. The olive oils examined in the present study manifested relative purity. The refractive index of 1.467 at $25{ }^{\circ} \mathrm{C}$ showed that it is not as thick as most drying oil whose refractive indices fell between 1.475 and 1.485 (Ogungbenle and Afolayan, 2015).

It was found that the effect of storage time on refractive index of olive oil samples was statically significant $(p<0.01)$. The effect of irradiation treatment on RI of olive oil samples was found insignificant $(p>0.05)$ except for the measurement at zero time (Table 3). In agreement with our results, Arici et al. (2007) reported that the effect of irradiation exposure on refractive index of black cumin seed samples was found insignificant.

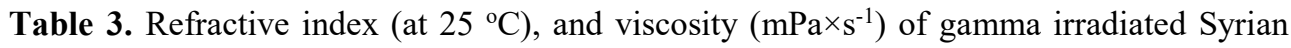
Kaissy Olive Oil (SKOO) and stored for up to 36 months.

\begin{tabular}{|c|c|c|c|c|c|}
\hline $\begin{array}{l}\text { Treat- } \\
\text { ment }\end{array}$ & Control & $1 \mathrm{KGY}$ & 2 KGY & $3 \mathrm{KGY}$ & $\begin{array}{l}\text { P- } \\
\text { level }\end{array}$ \\
\hline \multicolumn{6}{|c|}{ Storage period/(Months) } \\
\hline \multicolumn{6}{|c|}{ Refractive Index (at $25^{\circ} \mathrm{C}$ ) } \\
\hline 0 & $1.4670 \pm 0.00^{\mathrm{aB}}$ & $1.4560 \pm 0.00^{\mathrm{bC}}$ & $1.4659 \pm 0.00^{\mathrm{cB}}$ & $1.4657 \pm 0.00^{\mathrm{cbD}}$ & ** \\
\hline 6 & $1.4652 \pm 0.00^{\mathrm{cbE}}$ & $1.4651 \pm 0.00^{\mathrm{cD}}$ & $1.4658 \pm 0.00^{\mathrm{aB}}$ & $1.4655 \pm 0.00^{\mathrm{abE}}$ & * \\
\hline 12 & $1.4658 \pm 0.00^{\mathrm{aD}}$ & $1.4659 \pm 0.00^{\mathrm{aC}}$ & $1.4659 \pm 0.00^{\mathrm{aB}}$ & $1.4659 \pm 0.00^{\mathrm{aC}}$ & NS \\
\hline 24 & $1.4664 \pm 0.00^{\mathrm{aC}}$ & $1.4665 \pm 0.00^{\mathrm{aB}}$ & $1.4673 \pm 0.00^{\mathrm{aA}}$ & $1.4668 \pm 0.00^{\mathrm{aB}}$ & NS \\
\hline 36 & $1.4685 \pm 0.00^{\mathrm{aA}}$ & $1.4679 \pm 0.00^{\mathrm{bA}}$ & $1.4680 \pm 0.00^{\mathrm{aA}}$ & $1.4680 \pm 0.00^{\mathrm{aA}}$ & $* *$ \\
\hline P-level & $* *$ & ** & $* *$ & $* *$ & \\
\hline \multicolumn{6}{|c|}{ Viscosity $\left(\mathrm{mPa} \times \mathrm{s}^{-1}\right)$} \\
\hline 0 & $137.67 \pm 0.58^{\mathrm{bC}}$ & $137.67 \pm 0.58^{\mathrm{bC}}$ & $138.67 \pm 0.58^{\mathrm{abC}}$ & $139.67 \pm 0.58^{\mathrm{aC}}$ & ** \\
\hline 6 & $134.00 \pm 1.00^{\mathrm{abD}}$ & $133.33 \pm 0.58^{\mathrm{bD}}$ & $134.00 \pm 1.00^{\mathrm{abD}}$ & $135.67 \pm 1.16^{\mathrm{aD}}$ & NS \\
\hline 12 & $149.67 \pm 0.58^{\mathrm{abB}}$ & $150.33 \pm 0.58^{\mathrm{aB}}$ & $149.00 \pm 1.00^{\mathrm{bB}}$ & $149.33 \pm 0.58^{\mathrm{abB}}$ & NS \\
\hline 24 & $130.00 \pm 0.00^{\mathrm{aE}}$ & $129.67 \pm 0.58^{\mathrm{aE}}$ & $130.33 \pm 0.58^{\mathrm{aE}}$ & $130.67 \pm 0.58^{\mathrm{aE}}$ & NS \\
\hline 36 & $154.33 \pm 1.53^{\mathrm{aA}}$ & $154.67 \pm 2.08^{\mathrm{aA}}$ & $154.67 \pm 1.53^{\mathrm{aA}}$ & $154.67 \pm 1.15^{\mathrm{aA}}$ & NS \\
\hline P-level & $* *$ & $* *$ & $* *$ & $* *$ & \\
\hline
\end{tabular}

abc Significant difference between storage periods are presented with different superscript $\left({ }^{*} \mathrm{p}<0.05,{ }^{* *} \mathrm{p}<0.01\right)$.

$\mathrm{ABC}$ Significant difference between irradiation treatments are presented with different superscript $\left({ }^{*} \mathrm{p}<0.05,{ }^{* *} \mathrm{p}<0.01\right)$.

NS: not significant. 


\section{Effect of gamma irradiation treatment and storage period on viscosity of olive oil}

The viscosities of the untreated and gamma irradiated SKOO are shown in Table 3. The viscosity of $137.67 \mathrm{mPa}$.S registered for non irradiated SKOO was higher than those of most vegetable oils as reported by Besbes et al. (2005). This could be explained by the high content of monounsaturated and poly unsaturated fatty acids as previously reported by Geller and Goodrum (2000). Increasing the gamma irradiation doses to 2 and $3 \mathrm{kGy}$ and duration the storage to 12 and 36 months increased viscosity over the oil gamma irradiated at $3 \mathrm{kGy}$ and stored for 36 months. Increased viscosity after microwave irradiation was previously reported for olive, sunflower and soybean oils (Biswas et al., 2007).

\section{Conclusions}

To the best of our knowledge, this is the first study on the characterization of olive oil of Kaissy cultivar harvested from southern Syrian location and treated with different doses of gamma irradiation (1, 2, and $3 \mathrm{kGy})$. The analytical parameters studied for irradiated and non-irradiated Syrian Kaissy Olive Oil (SKOO) including acid value (AV), peroxide value (PV), TBA number, iodine value (IV) specification value (SV), refractive index (RI) and viscosity were within the limits recommended by the international olive council (IOC, 2015) for the high quality category "virgin" olive oils. In addition, the studied qualitative characteristics were significantly influenced by the used doses of gamma irradiation and storage time.

\section{Acknowledgements}

The authors are grateful wish to the Director General of the Syrian Atomic Energy Commission (SAEC) and the staff of food irradiation group.

\section{References}

Afify, A.M.R., Rashed. M.M., Ebtesam, A.M. and El-Beltagi, H.S. 2013. Effect of gamma radiation on the lipid profiles of soybean, peanut and sesame seed oils. Grasas $y$ Aceites, 64(4), 356-368.

Agatemor, C. 2006. Studied of selected physicochemical properties of fluted pumpkin (Telfairia occidentalis Hook F) seed oil and tropical almond (Terminalia catappia L.) seed oil. Pakistan Journal of Nutrition, 5, 306-307.

Al-Bachir, M. 2004. Effect of gamma irradiation on fungal load, chemical and sensorycharacteristics of walnuts (Juglans regia L.). Journal of Stored Products Research, 40, 355-362.

Al-Bachir, M. and Zeino R. 2006. Effect of gamma irradiation on some characteristics of shell eggs and mayonnaise prepared from irradiated eggs. Journal of Food Safety, 26, $348-360$.

Al-Bachir, M. 2013. Microbiological Load and Quality Characteristics of Irradiated Chicken Meat. Arab Golf. Journal of Scientific Research, 31(1), 59-67.

Al-Bachir, M. 2014. Physicochemical properties of oil extracts from gamma irradiated almond (Prunus amygdalus L.). Innovative Romanian Food Biotechnology, 14, 37-45. 
Al-Bachir, M. 2015a. Quality characteristics of oil extracted from gamma irradiated peanut (Archis hypogea L.). Radiation Physics and Chemistry, 106, 56-60.

Al-Bachir, M. 2015b. Studies on the physicochemical characteristics of oil extracted from gamma irradiated pistachio (Pistacia vera L.). Food Chemistry, 167, 175-179.

Al-Bachir, M. 2017. Comparison of fruit characteristics, oil properties and fatty acid composition of native Syrian Kaissy cv olive (Olea europaea). Journal of Food Measurement and Characterization, 11, 1011-1018.

Al-Harbi, M.M., Al-Kabtani H.A. 1993. Chemical and biological evaluation of discarded frying palm oil in commercial restaurants. Food Chemistry, 48, 395-401.

AOAC (2010). Official Methods of Analysis. 15 $5^{\text {th }}$ edn. Association of Official Analytical Chemists, Washington, D.C.

Arici, M., Colak, F.A., Gecgel U. 2007. Effect of gamma radiation on microbiological and oil properties of black cumin (Nigella sativa L.). Grasa y Aceites, 58(4), 339-343.

Atinafu, D.G, Bedemo B. 2011. Estimation of total free fatty acid and cholesterol content in some commercial edible oils in Ethiopia DAR. Journal of Cereals and Oil Seeds, 2, 71-76.

Baiano, A., Terracone, C., Viggian, I., Del Nobile, M.A. 2014. Changes produced in extravirgin olive oils from cv. Coratina a prolonged storage treatment. Czech Journal of Food Science, 32(1), 1-9.

Barbaro, B., Toietta, G., Maggio, R., Arciello, M., Tarocchi, M., Galli, A. Balsano, C. 2014. Effects of the olive derived polyphenol pleuropein on human health. International Journal MolecularScience, 15, 18508-18524.

Besbes, S., Blecker, C., Deroanne, C., Lognay, G., Drira, N.E., Attia, H. 2005. Quality characteristics and oxidative stability of date seed oil during storage. Food Science Technology International, 10, 333-338.

Bhatti, I.A., Iqball, M., Anwar, F., Shahid, S.A., Shahid M. 2013. Quality characteristics and microbiological safety evaluation of oils extracted from gamma irradiated almond (Prunus dulcis Mill.) seeds. Grasas y Aceites, 64(1), 68-76.

Biswas, T.K., Sana, N.K., Badal, R., Huque, E.M. 2001. Biochemical study of some oil seeds (brassica, sesame and linseed). Pakistan Journal of Biological Sciences, 4(8), 1002-1005.

Biswas, A., Adhvaryu, A., Stevenson, D.G., Sharma, B.K., Willet, J.L. Erhan, S.Z. 2007. Microwave irradiation effects on the structure, viscosity, thermal properties and lubricity of soybean oil. Industrial Crops and Products, 25, 1-7.

Blatchly, R.A., Delen, Z., O'Hara, P.B. 2014. Making sense of olive oil: Simple experiments to connect sensory observations with the underlying chemistry. Journal of Chemical Education, 91(10), 1623-1630.

Enujiugha, V.N., Thani, F.A., Sanni, T.M., Abigor, R.D. 2004. Lipase activity in dormant seeds of the African oil bean (Pentaclethra macrophylla Benth). Food Chemistry, 88, 405-410.

Enujiugha, V.N., Olotu, I.O., Malomo, S.A. 2012. The effect of gamma irradiation and cooking on physicochemical properties of African oil bean seed (Pentaclethra macrophylla benth) and its oil extract. Journal of Food Research, 1(2), 189-201.

Erkan, N., Ozden, O. 2007. The changes of fatty acid and amino acid composition in sea bream (Sparus aurata) during irradiation process. Radiation Physics and Chemistry, 76(10), 1636-1641. 
Gamli, O.F., Hayoglu, I. 2007. The effect of the different packaging and storage conditions on the quality of pistachio nut paste. Journal of Food Engineering, 78, 443-448.

Geller, D.P, Goodrum, J.W. 2000. Rheology of vegetable oil analogs and triglycerides. Journal of American Oil Chemist,s Society, 77, 111-114.

International Olive Council (IOC). 2015. Trade standard applying to olive oils and olive pomace oil. COI/T.15/NC No 3/Rev.9 June 2015. p. 17.

IUPAC. 1992. Determination of 2-thiobarbituric acid Value: Direct Method.Vol.61, No, 6 , PP.1165-1170. Standard Methods for the Analysis of Oils, Fats and Derivates, 7th edn (Paquot C; Hautffenne A, eds). International Union of Pure and Applied Chemistry, Blackwell Scientific Publications Inc., Oxford, UK.

Jenisova, Z., Branisa, J., Jomova, K., Porubska, M. 2014. Variations of some nutrition values of oil by household using. Journal of Microbiology, Biotechnology and Food Science, 3(3), 221-224.

Nwinuka, N.M., Barine, I.N. 2009. Physico-chemical properties and fatty acid composition of dennettia tripetala fruit oil (Pepper fruit). Nigerian Journal of Biochemistry and Molecular Biology, 24, 42-46.

Ogungbenle, H.N., Afolayan, M.F. 2015. Physical and chemical characteristics of roasted cashew nut (Anacardium occidentale) flour and oil. International Journal of Food Science and Nutrition Engineering, 5(1), 1-7.

Olotu, I., Enujiugha, V., Obadina, A., Owolabi, K. 2014. Fatty acid profile of gamma irradiated and cooked African oil bean seed (Pentraclethra macrophylla Benth). Food Science and Nutrition, 2(6), 786-791.

Papadimitriou, V., Sotiroudis, T.G., Xenakis, A., Sofikiti, N., Stavyiannoudaki, V., Chaniotakis, N.A. 2006. Oxidative stability and radical scavenging activity of extra virgin olive oils: An electron paramagnetic resonance spectroscopy study. Analytical Chemica Acta, 537, 453-458.

Psomiadou, E., Tsimidou, M. 2002. Stability of virgin olive oil. 2. Photo-oxidation studies. Journal of Agricultural and Food Chemistry, 50, 722-727.

Snedecor, G., Cochran, W. 1988. Statistical methods. The Iowa State University Press, Ames, Aiwa, pp. 221-221.

Velasco, J., Dobarganes, C. 2002. Oxidative stability of virgin olive oil (Review). European Journal of Lipid Science and Technology, 104(9-10), 661-676.

Zegane, O., Keciri, S., Louaileche, H. 2015. Physicochemical characteristics and pigment content of Algerian olive oils: Effect of olive cultivar and geographical origin. International Journal of Chemical and Biomolecular Science, 1(3), 153-157. 